JURNAL BALI MEMBANGUN BALI

Volume 1 Nomor 2, Agustus 2020

e-ISSN 2722-2462 p-ISSN 2722-2454

http://ejournal.baliprov.go.id/

\title{
Pengobatan Tradisional Bali Usadha Tiwang
}

\author{
I Nyoman Arsana ${ }^{1}$, I Putu Sudiartawan ${ }^{2}$, Ni Luh Gede Sudaryati ${ }^{3}$, \\ I Made Agus Gelgel Wirasuta ${ }^{4}$, Pande Made Nova Armita ${ }^{5}$, Ni Kadek Warditiani ${ }^{6}$, \\ Ni Made Widi Astuti ${ }^{7}$, I Wayan Martadi Santika ${ }^{8}$, \\ Ida Bagus Wiryanatha ${ }^{9}$, Putu Lakustini Cahyaningrum ${ }^{10}$, Ida Bagus Putra Suta ${ }^{11}$. \\ 1,2,3Program Studi Biologi, Universitas Hindu Indonesia \\ 4,5,6,7,8 Program Studi Farmasi Universitas Udayana \\ 9,10,11Program Studi Ayurweda, Universitas Hindu Indonesia \\ Email : ${ }^{1}$ arsanacita@gmail.com
}

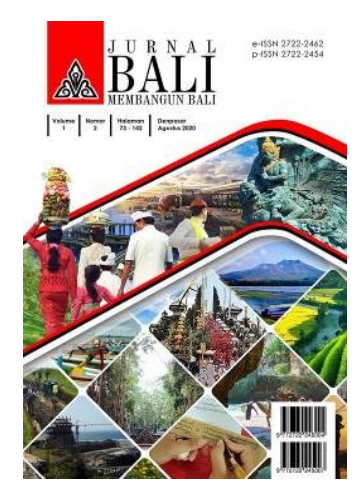

Sejarah Artikel

Diterima pada 23 Juni 2020

Direvisi pada 26 Juni 2020

Disetujui pada 27 Juni 2020

\section{Abstrak}

Tujuan: Artikel ini bertujuan untuk mengkaji pengobatan tradisional Bali, dengan mengambil fokus kajian pada pengobatan yang tertuang dalam lontar Usadha Tiwang.

Metode penelitian: Penelitian ini menggunakan metode kepustakaan (Library Research). Unit analisis berupa naskah lontar Usadha Tiwang, yang telah ditransliterasi dari aksara Bali ke aksara Latin.

Temuan: Hasil penelitian diketahui bahwa tiwang adalah penyakit yang mempunyai gejala badan terasa meluang, sakit dan ngilu, gelisah, mata mendelik, otot kaku bahkan sampai pingsan. Jenis tiwang dicirikan berdasarkan gejala yang muncul. Pengobatan dilaksanakan secara holistik oleh pengusada sesuai tatalaksana pengusada, dengan menggunakan ramuan obat-obatan yang terbuat dari campuran berbagai jenis tumbuh-tumbuhan atau bahan lainnya seperti arak, lengis tanusan, garam, gula, kapur, maupun santen, bahkan tain seksek serta iduh bang. Penggunaannya dengan cara dimakan, diminum, ditutuhkan, disemburkan, diuapkan atau dilulurkan, maupun ditempelkan. Takaran, cara pengolahan, serta cara pemakaian masih belum jelas.

Implikasi: Masyarakat Bali tetap percaya terhadap sistim pengobatan tradisional Bali. Namun demikian, masyarakat Bali yang berobat ke tempat praktik pengobatan tradisional sangat sedikit. Simpulannya adalah pengobatan tradisional Bali dilakukan secara holistik untuk mencapai keseimbangan antara shtula sarira-suksma sariraantahkarana sarira.

Kata kunci: pengobatan tradisional Bali, Usadha Tiwang, tanaman obat.

\section{Abstract}

Purpose: This article aims to study traditional Balinese medicine, by taking the focus of the study on the treatments mentioned in Lontar Usadha Tiwang.

Research methods: This research uses the library research method. The unit of analysis is the manuscript of Lontar Usadha Tiwang, which has been transliterated from the Balinese script to the Latin script.

Findings: The results of the study are known that tiwang is a disease that has symptoms of the body of pain, anxious, glared eyes, stiff muscles and even faint. The type of tiwang is characterized by symptoms that arise. Treatment is carried out holistically by the pengusada in accordance with the management of the pengusada, by using a medicinal herb made from a mixture of various types of plants or other ingredients such as arak (Balinese wine), lengis tanusan (traditional coconut oil), salt, sugar, whiting, and coconut milk, even tain seksek (wood dust produced by woodeating insects) and iduh bang (red saliva after eating betel). Its use is by being eaten, drunk, dripped, sprayed with mouth, scrubbed, or sticked. The dosage, method of processing, and method of use are still unclear.

Implications: Balinese community still believe in the traditional Balinese medicine which is called Usadha. In conclusion, Balinese traditional medicine is carried out holistically to achieve a balance between Shtula Sarira-Suksma Sarira-Antahkarana Sarira.

Keywords: traditional balinese medicine, usadha tiwang, medicinal plant 


\section{PENDAHULUAN}

Kesehatan merupakan suatu keadaan sehat, baik secara fisik, mental, spritual maupun sosial yang memungkinkan setiap orang untuk hidup produktif secara sosial dan ekonomis. Untuk mewujudkan derajat kesehatan yang setinggi-tingginya bagi masyarakat, diselenggarakan upaya kesehatan yang terpadu dan menyeluruh dalam bentuk upaya kesehatan perseorangan dan upaya kesehatan masyarakat. Upaya kesehatan diselenggarakan dalam bentuk kegiatan dengan pendekatan promotif, preventif, kuratif, dan rehabilitatif yang dilaksanakan secara terpadu, menyeluruh, dan berkesinambungan. Penyelenggaraan upaya kesehatan tersebut salah satunya dapat dilaksanakan melalui kegiatan pelayanan kesehatan tradisional. Pelayanan kesehatan tradisional adalah pengobatan dan/atau perawatan dengan cara dan obat yang mengacu pada pengalaman dan keterampilan turun temurun secara empiris yang dapat dipertanggungjawabkan dan diterapkan sesuai dengan norma yang berlaku di masyarakat (UU RI 36/2009).

Pengobatan Tradisional Bali mengacu pada tradisi, pengalaman, keterampilan turun-temurun masyarakat Bali, baik yang belum tercatat maupun yang telah terliterasi dalam lontar usada ataupun dalam pendidikan atau pelatihan, dan diterapkan sesuai dengan norma yang berlaku dalam masyarakat Bali (PerGub Bali No 55 Tahun 2019) . Masyarakat Bali tetap percaya terhadap sistim pengobatan tradisional Bali. Hal ini karena masyarakat Bali percaya bahwa sehat-sakit terjadi merupakan kombinasi shtula sarira-suksma sarira-antahkarana sarira yakni keseimbangan antara badan (Body), pikiran (Mind), dan jiwa (spirit). Disamping itu, saat ini ada kecenderungan masyarakat beralih menggunakan bahan-bahan alami dalam meningkatkan kesehatan dan kebugarannya. Namun demikian, masyarakat Bali yang berobat ke tempat praktik batra atau pengobatan alternatif hanya mencapai $1,03 \%$, dibandingkan berobat ke praktik dokter atau bidan yang mencapai 57,96 \% (BPS, 2019).

Ada indikasi bahwa praktik pengobatan tradisional Bali masih ketinggalan jauh dengan praktik pengobatan tradisional di Negara lain, seperti praktik pengobatan Traditional Chinise Medicine (TCM) sejak ribuan tahun lalu , yang berdasarkan pada konsep yin-yang dan Wuxing serta menggunakan berbagai macam ramuan (Yuan et al., 2016), praktik pengobatan ayurwedic di India dengan tiga elemen Pitta-KaphaVata (Ventegodt et al., 2007). Karena itulah maka kajian tentang pengobatan tradisional Bali penting untuk dilakukan karena pengetahuan tradisional tentang pengobatan Usada Bali adalah salah satu kekayaan bangsa Indonesia yang perlu dijaga sehingga 
tidak diklaim dan dipatenkan oleh bangsa lain. Pengetahuan ini dapat memiliki nilai unggul, kompetitif dan inovatif dari masyarakat Bali dan masyarakat Indonesia.

Artikel ini bertujuan untuk mengkaji pengobatan tradisional Bali, dengan mengambil fokus kajian pada pengobatan yang tertuang dalam Iontar Usadha tiwang, dengan harapan dapat menjadi salah satu referensi dalam pengembangan pengobatan tradisional Bali empiris, pengobatan tradisional Bali komplementer dan pengobatan tradisional integratif.

\section{KAJIAN SUMBER DAN METODE PENELITIAN}

Penelitian ini menggunakan metode kepustakaan (Library Research). Unit analisis berupa naskah lontar Usadha Tiwang. Naskah lontar tersebut berupa naskah lontar yang telah ditransliterasi dari aksara Bali ke aksara Latin, namun demikian penyebutan lontar masih digunakan sesuai kebiasaan umum di masyarakat. Deskripi lontar Usadha Tiwang; Verzameld door Kirtya, Uit Boesongbio (Pengastoelan), Ontvangen 10 April 1933, Getik 12 Desember 1941, Door Ni Made Tirta, Nagakeken door Ketoet Kabir. Lontar tersebut diperkirakan telah ada sebelum tahun 1933 (Gambar 1).

Lontar tersebut kemudian ditelusuri cara atau metode pengobatan untuk berbagai jenis penyakit dengan menggunakan sarana atau campuran bahan yang terutama berupa ramuan dari tumbuh-tumbuhan. Data yang diperoleh dianalisis secara deskriptif kualitatif.

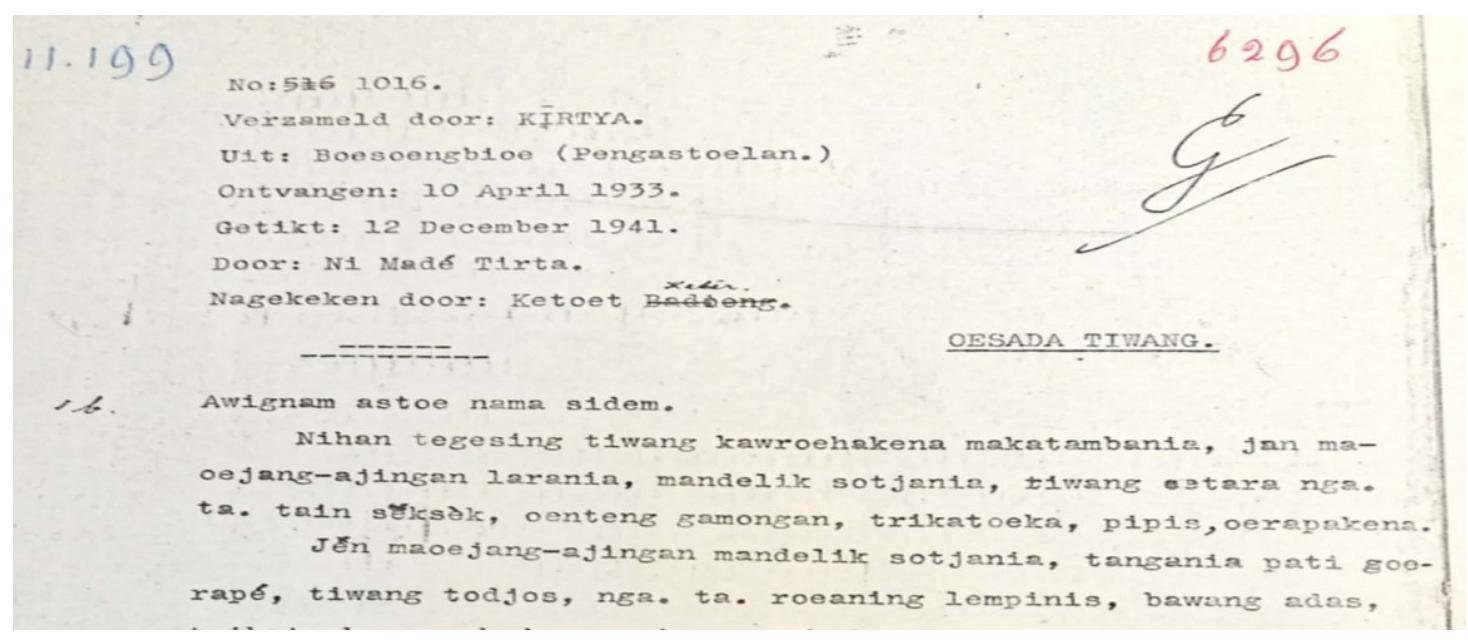

Gambar 1. Naskah Lontar Usadha Tiwang Yang Telah Mengalami Transliterasi. 


\section{PEMBAHASAN}

Pengobatan tradisional Bali seperti tertulis dalam lontar usadha tiwang terutama membahas tentang penyakit tiwang. Tiwang adalah penyakit yang mempunyai gejala badan terasa meluang, sakit dan ngilu, gelisah, mata mendelik, otot kaku bahkan sampai pingsan. Jenis tiwang dicirikan berdasarkan gejala yang muncul, seperti tiwang utara memiliki gejala gelisah (meunyang-anyingan), mata mendelik. Tiwang tojos dicirikan dengan gejala gelisah (meunyang-anyingan), mata mendelik, serta tangan tidak mau diam (pati grèpè). Tiwang udang memiliki gejala tangan dan tungkai bergerak-gerak seperti gerakan udang, mata melotot. Di samping itu, lontar usadha tiwang menyebutkan penyakit lainnya seperti batuk, mokan yaitu penyakit dengan gejala bengkak dan terasa sakit. Berbagai jenis penyakit atau gejala penyakit disajikan pada tabel 1.

Tabel 1. Penyakit atau gejala pengakit dan cara pengobatannya dalam Lontar Usadha Tiwang

\begin{tabular}{|c|c|c|c|}
\hline Penyakit & Gejala & Campuran Bahan Obat & Cara pengobatan \\
\hline $\begin{array}{l}\text { Tiwang } \\
\text { utara }\end{array}$ & $\begin{array}{l}\text { Meunyang-anyingan } \\
\text { (gelisah), mata } \\
\text { mendelik }\end{array}$ & $\begin{array}{l}\text { Gamongan (Zingiber zerumbet), Triketuka \{Kesuna } \\
\text { (Allium sativum L), Jangu (Acorus calamus), Mesui } \\
\text { (Cryptocarya massoy (Oken) Kosterm.)\}, Tain } \\
\text { seksek }\end{array}$ & $\begin{array}{l}\text { Semuanya } \\
\text { dihaluskan } \\
\text { kemudian } \\
\text { diurapkan }\end{array}$ \\
\hline $\begin{array}{l}\text { Tiwang } \\
\text { tojos }\end{array}$ & $\begin{array}{l}\text { Gelisah, mata } \\
\text { mendelik, tangan tidak } \\
\text { mau diam }\end{array}$ & $\begin{array}{l}\text { Daun Lempinis, Bawang adas (Eleutherine } \\
\text { palmifolia), Triketuka }\{\text { Kesuna (Allium sativum L), } \\
\text { Jangu (Acorus calamus), Mesui (Cryptocarya } \\
\text { massoy (Oken) Kosterm.)\}, } \\
\text { Daun intaran (Azadirachta indica), Daun awar-awar } \\
\text { (Ficus septica), Arak, Sarang laba-laba di tembok }\end{array}$ & $\begin{array}{l}\text { Hidungnya ditutuh } \\
\text { dan diminum } \\
\text { Dihaluskan } \\
\text { kemudian diminum }\end{array}$ \\
\hline Tiwang alun & Perut terasa sakit & $\begin{array}{l}\text { Gamongan (Zingiber zerumbet), Daun teep } \\
\text { (Artocarpus elasticus Reinw.ex Blume), Triketuka } \\
\text { \{Kesuna (Allium sativum L), Jangu (Acorus } \\
\text { calamus), Mesui (Cryptocarya massoy (Oken) } \\
\text { Kosterm.)\}, Bras bang (Oryza nivara), Jeruk linglang } \\
\text { (Citrus aurantifolia). }\end{array}$ & $\begin{array}{l}\text { Dihaluskan } \\
\text { kemudian diminum }\end{array}$ \\
\hline $\begin{array}{l}\text { Tiwang } \\
\text { pamali } \\
\text { papasanan }\end{array}$ & $\begin{array}{l}\text { Punggung terasa sakit } \\
\text { menusuk-nusuk }\end{array}$ & $\begin{array}{l}\text { Daun dan babakan pule (Alstonia scholaris (L.) R. } \\
\text { Br.), Temu tis (Curcuma purpurascens Blume), } \\
\text { Sepet-sepet, Tingkih (Aleurites moluccanus (L.) } \\
\text { Willd), Kelapa dibakar (Cocos nucifera L), Adas } \\
\text { (Foeniculum vulgare). }\end{array}$ & $\begin{array}{l}\text { Dihaluskan } \\
\text { kemudian } \\
\text { disembarkan }\end{array}$ \\
\hline Tiwang jasa & Tangan meluang & $\begin{array}{l}\text { Pancasona (Merremia mammosa), Kangkang yuyu, } \\
\text { Adas (Foeniculum vulgare) }\end{array}$ & $\begin{array}{l}\text { Dihaluskan } \\
\text { kemudian } \\
\text { disembarkan }\end{array}$ \\
\hline $\begin{array}{l}\text { Tiwang } \\
\text { mong }\end{array}$ & $\begin{array}{l}\text { Setiap malam terasa } \\
\text { sakit menusuk-nusuk } \\
\text { dan denyut-denyut }\end{array}$ & $\begin{array}{l}\text { Akar tuwung kanji (Solanum surattense), Babakan } \\
\text { maja (Aegle marmelos), Tarekepan danyuh (Cocos } \\
\text { nucifera L). }\end{array}$ & $\begin{array}{l}\text { Dihaluskan } \\
\text { ditambah idu bang } \\
\text { (ludah warna } \\
\text { merah setelah } \\
\text { makan sirih) } \\
\text { kemudian } \\
\text { diurapkan }\end{array}$ \\
\hline Tiwang asu & $\begin{array}{l}\text { Terasa sakit tercabik- } \\
\text { cabik (menyokot- } \\
\text { nyokot) }\end{array}$ & $\begin{array}{l}\text { Kunir (Curcuma demostica), Tabia bungkut (Piper } \\
\text { retrofractum, Piper longum L), Trikatuka \{Kesuna } \\
\text { (Allium sativum L), Jangu (Acorus calamus), Mesui } \\
\text { (Cryptocarya massoy (Oken) Kosterm.)\}, Daging } \\
\text { kameri (Aleurites moluccanus (L.) Willd). }\end{array}$ & $\begin{array}{l}\text { Dihaluskan } \\
\text { kemudian } \\
\text { diurapkan }\end{array}$ \\
\hline Tiwang udel & $\begin{array}{l}\text { Pusar terasa sakit, } \\
\text { perut kaku (kenyat) }\end{array}$ & $\begin{array}{l}\text { Kulit pangi yang telah dibakar (Pangium edule), } \\
\text { Idubang, Trikatuka }\{\text { Kesuna (Allium sativum L), } \\
\text { Jangu (Acorus calamus), Mesui (Cryptocarya } \\
\text { massoy (Oken) Kosterm.), Lenge (Sesamum } \\
\text { indicum L.). }\end{array}$ & $\begin{array}{l}\text { Dihaluskan } \\
\text { kemudian } \\
\text { diurapkan di pusar }\end{array}$ \\
\hline Tiwang & Mulut menganga dan & Daun tube jenu, Kayu nyali, Triketuka $\{$ Kesuna & Dihaluskan \\
\hline
\end{tabular}




\begin{tabular}{|c|c|c|c|}
\hline mang & kaku & $\begin{array}{l}\text { (Allium sativum L), Jangu (Acorus calamus), Mesui } \\
\text { (Cryptocarya massoy (Oken) Kosterm.)\}. }\end{array}$ & $\begin{array}{l}\text { kemudian dipakai } \\
\text { sebagai bedak. }\end{array}$ \\
\hline $\begin{array}{l}\text { Tiwang } \\
\text { bangke }\end{array}$ & Kaku seperti mayat & Remek daging & $\begin{array}{l}\text { Ditumbuk } \\
\text { kemudian dipakai } \\
\text { sebagai bedak }\end{array}$ \\
\hline $\begin{array}{l}\text { Tiwang } \\
\text { gurita }\end{array}$ & $\begin{array}{l}\text { Kaku seluruh lengan } \\
\text { dan tungkai, tangan } \\
\text { mencengkram seperti } \\
\text { ikan gurita }\end{array}$ & $\begin{array}{l}\text { Daun madori kuning (Calotropis gigantean), } \\
\text { Trikatuka \{Kesuna (Allium sativum L), Jangu (Acorus } \\
\text { calamus), Mesui (Cryptocarya massoy (Oken) } \\
\text { Kosterm.)\}, Bawang putih (Allium sativum L), Adas } \\
\text { (Foeniculum vulgare), Tingkih (Aleurites moluccanus } \\
\text { (L.) Willd). }\end{array}$ & $\begin{array}{l}\text { Dihaluskan } \\
\text { kemudian } \\
\text { disembarkan }\end{array}$ \\
\hline $\begin{array}{l}\text { Tiwang } \\
\text { garuda }\end{array}$ & $\begin{array}{l}\text { Rahang kaku, perut } \\
\text { sakit sampai ke } \\
\text { siksikan, tangan } \\
\text { tergenggam }\end{array}$ & $\begin{array}{l}\text { Daun kapasilan (Viscum articulatum), Trikatuka } \\
\text { \{Kesuna (Allium sativum L), Jangu (Acorus } \\
\text { calamus), Mesui (Cryptocarya massoy (Oken) } \\
\text { Kosterm.)\}. }\end{array}$ & $\begin{array}{l}\text { Dihaluskan dan } \\
\text { digunakan sebagai } \\
\text { bedak. }\end{array}$ \\
\hline $\begin{array}{l}\text { Tiwang } \\
\text { lunak }\end{array}$ & $\begin{array}{l}\text { Hulu hati terasa enek } \\
\text { dan meluang }\end{array}$ & $\begin{array}{l}\text { Babakan kelor (Moringa oleifera L), Lampuyang } \\
\text { (Zingiber zerumbet) }\end{array}$ & $\begin{array}{l}\text { Dihaluskan } \\
\text { kemudian } \\
\text { disembar perutnya } \\
\text { dan hulu hatinya. }\end{array}$ \\
\hline $\begin{array}{l}\text { Tiwang } \\
\text { papasangan }\end{array}$ & $\begin{array}{l}\text { Badan terasa sakit } \\
\text { seperti terikat } \\
\text { (bedbed) }\end{array}$ & Karuk (Piper sarmentosum), Air arak & $\begin{array}{l}\text { Dipakai sebagai } \\
\text { bedak }\end{array}$ \\
\hline $\begin{array}{l}\text { Tiwang } \\
\text { jangat }\end{array}$ & $\begin{array}{l}\text { Perut begah, badan } \\
\text { terasa remuk, tidak } \\
\text { bisa kencing }\end{array}$ & $\begin{array}{l}\text { Sembung rambat (Tournefortia sarmentosa Lam.), } \\
\text { Antawali (Tinospora crispa), Pijer, Bawang adas } \\
\text { (Eleutherine palmifolia), Bras (Oryza sativa). }\end{array}$ & $\begin{array}{l}\text { Sembar hulu } \\
\text { hatinya }\end{array}$ \\
\hline $\begin{array}{l}\text { Tiwang } \\
\text { bebek }\end{array}$ & $\begin{array}{l}\text { Perut } \text { ngredek seperti } \\
\text { suara lautan }\end{array}$ & $\begin{array}{l}\text { Sembung (Blumea balsamifera (L.) DC.), Daringo } \\
\text { (Acorus calamus) }\end{array}$ & \\
\hline $\begin{array}{l}\text { Tiwang } \\
\text { bawi }\end{array}$ & $\begin{array}{l}\text { Bengkak di samping } \\
\text { puser }\end{array}$ & $\begin{array}{l}\text { Kunyit warangan (Curcuma demostica), Kapkap } \\
\text { (Piper betle L), Triketuka \{Kesuna (Allium sativum L), } \\
\text { Jangu (Acorus calamus), Mesui (Cryptocarya } \\
\text { massoy (Oken) Kosterm.)\}, Bras bang (Oryza } \\
\text { nivara), Kapur mentah. }\end{array}$ & $\begin{array}{l}\text { Dipakai sebagai } \\
\text { bedak }\end{array}$ \\
\hline $\begin{array}{l}\text { Tiwang } \\
\text { sikaten }\end{array}$ & Perut terasa kaku & $\begin{array}{l}\text { Kelor (Moringa oleifera L), Munggi (Moringa oleifera } \\
\text { Lamk), Trikatuka }\{\text { Kesuna (Allium sativum L), Jangu } \\
\text { (Acorus calamus), Mesui (Cryptocarya massoy } \\
\text { (Oken) Kosterm.)\} }\end{array}$ & $\begin{array}{l}\text { Dipakai sebagai } \\
\text { sembar }\end{array}$ \\
\hline Tiwang utek & $\begin{array}{l}\text { Perut terasa begah } \\
\text { (embet) }\end{array}$ & Santen, Air kelapa (Cocos nucifera L), & Diminum \\
\hline $\begin{array}{l}\text { Tiwang } \\
\text { nanipi }\end{array}$ & $\begin{array}{l}\text { Perut sakit terasa } \\
\text { ngilut-ngilut, nusuk- } \\
\text { nusuk }\end{array}$ & $\begin{array}{l}\text { Babakan awar-awar (Ficus septica), Kasuna (Allium } \\
\text { sativum), Jangu (Acorus calamus). }\end{array}$ & Disebarkan \\
\hline $\begin{array}{l}\text { Tiwang } \\
\text { angin }\end{array}$ & $\begin{array}{l}\text { Sakit perut muncul } \\
\text { hilang }\end{array}$ & $\begin{array}{l}\text { Tunas liligundi lanang (Vitex trifolia L. ), Triketuka } \\
\text { \{Kesuna (Allium sativum L), Jangu (Acorus } \\
\text { calamus), Mesui (Cryptocarya massoy (Oken) } \\
\text { Kosterm.)\}, Lampuyang (Zingiber zerumbet), Lawos } \\
\text { (Alpinia galangal). } \\
\text { Triketuka \{Kesuna (Allium sativum L), Jangu (Acorus } \\
\text { calamus), Mesui (Cryptocarya massoy (Oken) } \\
\text { Kosterm.)\}, Kunir (Curcuma demostica). }\end{array}$ & $\begin{array}{l}\text { Dihaluskan } \\
\text { kemudian diminum }\end{array}$ \\
\hline $\begin{array}{l}\text { Tiwang } \\
\text { bangke }\end{array}$ & Kaku seperti mayat & $\begin{array}{l}\text { Babakan pule daha (Alstonia scholaris (L.) R. Br.), } \\
\text { Triketuka \{Kesuna (Allium sativum L), Jangu (Acorus } \\
\text { calamus), Mesui (Cryptocarya massoy (Oken) } \\
\text { Kosterm.)\}, Sintok (Cinamomum sintoc Bl.), Masui } \\
\text { (Cryptocarya massoy (Oken), Jebugarum (Myristica } \\
\text { fragrans Hout.), Sampar wantu (Sindora sumatrana } \\
\text { Miq.), Katik cengkeh (Syzygium aromaticum), } \\
\text { Katumbah (Coriandrum sativum L), Daun sumaga } \\
\text { bali (Citrus nobilis), Daun sedah (Piper betle L.), } \\
\text { Kunir (Curcuma demostica), Bras bang (Oryza } \\
\text { nivara), Mica gundil (Piper nigrum L). }\end{array}$ & $\begin{array}{l}\text { Dipakai sebagai } \\
\text { bedak }\end{array}$ \\
\hline $\begin{array}{l}\text { Tiwang } \\
\text { udang }\end{array}$ & $\begin{array}{l}\text { Tangan dan tungkai } \\
\text { bergerak-gerak seperti } \\
\text { gerakan udang, mata } \\
\text { melotot }\end{array}$ & $\begin{array}{l}\text { Kasela putih (Manihot utilissima), Jruk purut (Citrus } \\
\text { hystrix D. C), Trikatuka \{Kesuna (Allium sativum L), } \\
\text { Jangu (Acorus calamus), Mesui (Cryptocarya } \\
\text { massoy (Oken) Kosterm.)\}. }\end{array}$ & $\begin{array}{l}\text { Dipakai sebagai } \\
\text { bedak }\end{array}$ \\
\hline $\begin{array}{l}\text { Tiwang } \\
\text { kidang }\end{array}$ & $\begin{array}{l}\text { Sakit perut, tangan } \\
\text { serta tungkai bergerak } \\
\text { terus menerus }\end{array}$ & $\begin{array}{l}\text { Buah timbul yang masih kecil (kecalcilan) } \\
\text { (Artocarpus camansi), Trikatuka }\{\text { Kesuna (Allium } \\
\text { sativum L), Jangu (Acorus calamus), Mesui } \\
\text { (Cryptocarya massoy (Oken) Kosterm.)\}, Jebugarum } \\
\text { (Myristica fragrans Hout). }\end{array}$ & $\begin{array}{l}\text { Digerus sampai } \\
\text { halus kemudian } \\
\text { dipakai sebagai } \\
\text { bedak }\end{array}$ \\
\hline $\begin{array}{l}\text { Tiwang } \\
\text { dongkang }\end{array}$ & $\begin{array}{l}\text { Perut bengkak, mulut } \\
\text { berbusa }\end{array}$ & $\begin{array}{l}\text { Asem (Tamarindus indica), Jruk linglang (Citrus } \\
\text { aurantifolia). }\end{array}$ & $\begin{array}{l}\text { Tutuh hidungnya } \\
\text { dan diminum }\end{array}$ \\
\hline $\begin{array}{l}\text { Tiwang } \\
\text { lindung }\end{array}$ & $\begin{array}{l}\text { Sakit perut, badan } \\
\text { bergerak-gerak seperti } \\
\text { belut }\end{array}$ & $\begin{array}{l}\text { Padang blulang (Eleusine indica ( L) Gaertn), } \\
\text { Remek daging, Uyah areng }\end{array}$ & $\begin{array}{l}\text { Digunakan sebagai } \\
\text { obat degan cara } \\
\text { dimakan }\end{array}$ \\
\hline
\end{tabular}




\begin{tabular}{|c|c|c|c|}
\hline $\begin{array}{l}\text { Tiwang } \\
\text { kretas }\end{array}$ & $\begin{array}{l}\text { Bengkak di samping } \\
\text { puser, dahak terasa } \\
\text { lengket }\end{array}$ & $\begin{array}{l}\text { Daun dapdap tis (Erythrina variegate), Rimpang } \\
\text { kunyit (Curcuma demostica), Gula tebu }\end{array}$ & Diminum \\
\hline $\begin{array}{l}\text { Tiwang } \\
\text { blungsung }\end{array}$ & $\begin{array}{l}\text { Sakit perut, hulu hati } \\
\text { terasa sesak }\end{array}$ & $\begin{array}{l}\text { Sumanggi gunung (Hydrocotyle sibthorpioides Lam), } \\
\text { Lunak tanek (Tamarindus indica). }\end{array}$ & $\begin{array}{l}\text { Digerus (cakcak) } \\
\text { kemudian diperas, } \\
\text { disaring, airnya } \\
\text { direbus sedikit dan } \\
\text { diminum }\end{array}$ \\
\hline $\begin{array}{l}\text { Tiwang } \\
\text { tuwedan }\end{array}$ & $\begin{array}{l}\text { Badan terasa sakit } \\
\text { menusuk-nusuk, hulu } \\
\text { hati terasa sakit }\end{array}$ & $\begin{array}{l}\text { Daun nangka (Artocarpus heterophyllus Lam), Bras } \\
\text { barak (Oryza nivara), Isen kapur (Alpinia galangal). }\end{array}$ & $\begin{array}{l}\text { Digerus kemudian } \\
\text { disembar }\end{array}$ \\
\hline $\begin{array}{l}\text { Tiwang } \\
\text { bojog }\end{array}$ & $\begin{array}{l}\text { Alisnya maupun } \\
\text { mulutnya bergerak- } \\
\text { gerak seperti gerakan } \\
\text { kera. }\end{array}$ & $\begin{array}{l}\text { Babakan gintungan, } \\
\text { Dapdap tis (Erythrina variegate), Isen kapur (Alpinia } \\
\text { galangal), Katumbah (Coriandrum sativum L.) }\end{array}$ & $\begin{array}{l}\text { Dipakai sebagai } \\
\text { bedak kaki } \\
\text { Dipakai sebagai } \\
\text { sembar di hulu hati } \\
\text { dan di perut }\end{array}$ \\
\hline $\begin{array}{l}\text { Tiwang } \\
\text { bangke }\end{array}$ & $\begin{array}{l}\text { Punggung } \\
\text { melengkung, badan } \\
\text { terasa kaku tidak bisa } \\
\text { dibalik }\end{array}$ & $\begin{array}{l}\text { Jarak bang (Ricinus communis), Bayem bangke, } \\
\text { Bawang adas (Eleutherine palmifolia). }\end{array}$ & $\begin{array}{l}\text { Dipakai sebagai } \\
\text { bedak }\end{array}$ \\
\hline $\begin{array}{l}\text { Tiwang } \\
\text { bantang } \\
\text { ketungan }\end{array}$ & $\begin{array}{l}\text { Badan terasa sakit, } \\
\text { tengkurep di kaki, } \\
\text { tidak mampu } \\
\text { berbicara }\end{array}$ & $\begin{array}{l}\text { Kunir warangan (Curcuma demostica), Kapur sirih } \\
\text { Asaban cendana (Santalum album L.), Air jeruk } \\
\text { linglang (Citrus aurantifolia). }\end{array}$ & $\begin{array}{l}\text { Dipakai sebagi } \\
\text { bedak di kaki } \\
\text { Dipakai sebagai } \\
\text { obat minum }\end{array}$ \\
\hline $\begin{array}{l}\text { Tiwang } \\
\text { lomba- } \\
\text { lomba }\end{array}$ & $\begin{array}{l}\text { Terasa sakit di hulu } \\
\text { hati, di daerah pusar } \\
\text { terasa ngilut-ngilut, } \\
\text { gelisah }\end{array}$ & Akar blatung, Bras bang (Oryza nivara) & $\begin{array}{l}\text { Digerus sampai } \\
\text { halus kemudian } \\
\text { ditempelkan di } \\
\text { pusar. }\end{array}$ \\
\hline $\begin{array}{l}\text { Tiwang } \\
\text { bragenjang }\end{array}$ & $\begin{array}{l}\text { Perut terasa sakit } \\
\text { ngilut ngilut }\end{array}$ & $\begin{array}{l}\text { Sembung gantung (Tournefortia sarmentosa Lam.), } \\
\text { Miana cemeng (Coleus scutellarioides), Sulasih } \\
\text { miyik (Ocimum tenuiflorum), Uku-uku (Ocimum } \\
\text { gratissimum), Adas (Foeniculum vulgare). }\end{array}$ & $\begin{array}{l}\text { Digerus dan } \\
\text { disembar daerah } \\
\text { yang sakit. }\end{array}$ \\
\hline $\begin{array}{l}\text { Tiwang } \\
\text { tundol }\end{array}$ & $\begin{array}{l}\text { Siku singgak-singguk, } \\
\text { hulu hati berdebar } \\
\text { debar }\end{array}$ & $\begin{array}{l}\text { Lunak tanek (Tamarindus indica), Bras (Oryza } \\
\text { sativa), Kunir (Curcuma demostica), Mica gundil } \\
\text { (Piper nigrum L). }\end{array}$ & $\begin{array}{l}\text { Dibagai sbaegai } \\
\text { obat sembar di } \\
\text { daerah hulu hati }\end{array}$ \\
\hline $\begin{array}{l}\text { Tiwang } \\
\text { mong }\end{array}$ & & $\begin{array}{l}\text { Godong mer, Daun kembang kuning, Isen kapur } \\
\text { (Alpinia galangal), Katumbah (Coriandrum sativum } \\
\text { L.). }\end{array}$ & $\begin{array}{l}\text { Dipakai sebagai } \\
\text { sembar atau } \\
\text { bedak. }\end{array}$ \\
\hline $\begin{array}{l}\text { Tiwang } \\
\text { bangke }\end{array}$ & $\begin{array}{l}\text { Badan terasa sakit } \\
\text { meluang, mata } \\
\text { mendelik }\end{array}$ & $\begin{array}{l}\text { Kapkap (Piper betle L), Triketuka }\{\text { Kesuna (Allium } \\
\text { sativum L), Jangu (Acorus calamus), Mesui } \\
\text { (Cryptocarya massoy (Oken) Kosterm.)\} }\end{array}$ & $\begin{array}{l}\text { Digerus kemudian } \\
\text { dibedakkan }\end{array}$ \\
\hline $\begin{array}{l}\text { Tiwang be } \\
\text { julit }\end{array}$ & $\begin{array}{l}\text { Badan terasa sakit, } \\
\text { klijah-klijeh, landah- } \\
\text { londoh (bergerak } \\
\text { seperti ikan sidat) }\end{array}$ & $\begin{array}{l}\text { Padang kalia, Trikatuka }\{\text { Kesuna (Allium sativum L), } \\
\text { Jangu (Acorus calamus), Mesui (Cryptocarya } \\
\text { massoy (Oken) Kosterm.)\}, Suruh (Piper betle L). }\end{array}$ & $\begin{array}{l}\text { Dipakai sebagai } \\
\text { bedak }\end{array}$ \\
\hline $\begin{array}{l}\text { Tiwang } \\
\text { bantang }\end{array}$ & $\begin{array}{l}\text { Tangan maupun kaki } \\
\text { kejang-kejang, mata } \\
\text { mendelik }\end{array}$ & $\begin{array}{l}\text { Babakan munggi (Moringa oleifera Lamk), Isen } \\
\text { (Alpinia galangal), Trikatuka \{Kesuna (Allium sativum } \\
\text { L), Jangu (Acorus calamus), Mesui (Cryptocarya } \\
\text { massoy (Oken) Kosterm.)\} }\end{array}$ & $\begin{array}{l}\text { Dipakai sebagai } \\
\text { bedaknya }\end{array}$ \\
\hline $\begin{array}{l}\text { Tiwang } \\
\text { bangke }\end{array}$ & $\begin{array}{l}\text { Mata mendelik, } \\
\text { badannya lusuh }\end{array}$ & $\begin{array}{l}\text { Babakan pule (Alstonia scholaris (L.) R. Br.), } \\
\text { Dapdap tis (Erythrina variegate). }\end{array}$ & $\begin{array}{l}\text { Dipakai sebagai } \\
\text { bedaknya }\end{array}$ \\
\hline $\begin{array}{l}\text { Tiwang } \\
\text { bagor }\end{array}$ & $\begin{array}{l}\text { Mulut ngiler, capluk- } \\
\text { capluk seperti mulut } \\
\text { babi, mata mendelik }\end{array}$ & $\begin{array}{l}\text { Babakan intaran (Azadirachta indica), Trikatuka } \\
\text { \{Kesuna (Allium sativum L), Jangu (Acorus } \\
\text { calamus), Mesui (Cryptocarya massoy (Oken) } \\
\text { Kosterm.)\}, } \\
\text { Dedak }\end{array}$ & $\begin{array}{l}\text { Dipakai sebagai } \\
\text { bedaknya }\end{array}$ \\
\hline \multirow[t]{2}{*}{$\begin{array}{l}\text { Tiwang } \\
\text { desti }\end{array}$} & \multirow[t]{2}{*}{$\begin{array}{l}\text { Badan terasa sakit } \\
\text { meluang sampai ke } \\
\text { kaki }\end{array}$} & $\begin{array}{l}\text { Tengah, Akar medori putih (Calotropis gigantean), } \\
\text { Triketuka \{Kesuna (Allium sativum L), Jangu (Acorus } \\
\text { calamus), Mesui (Cryptocarya massoy (Oken) } \\
\text { Kosterm.)\}, Bras bang (Oryza nivara). } \\
\text { Kayu tulak (Schefflera elliptica), Kayu pugpug, Isen } \\
\text { kapur (Alpinia galangal), Putih telur, Luwun peken } \\
\text { (sampah pasar). } \\
\text { Kesambi (Schleichera oleosa Lour), Majekane } \\
\text { (Quercus lusitanica Lamk.), Majekling (Terminalia } \\
\text { citrine), Ganti lungid }\end{array}$ & $\begin{array}{l}\text { Dipakai sebagai } \\
\text { bedaknya } \\
\text { Dipakai sebagai } \\
\text { borek badan }\end{array}$ \\
\hline & & $\begin{array}{l}\text { Babakan kepah (Sterculia foetida), Bawang, } \\
\text { metambus (Allium cepa), Pulasai (Alyxia stellata } \\
\text { Auct non R\&S), Klungah (Cocos nucifera L). }\end{array}$ & $\begin{array}{l}\text { Dipakai sebagai } \\
\text { bedak di badan }\end{array}$ \\
\hline Belo & Perut sakit & $\begin{array}{l}\text { Babakan kelor (Moringa oleifera } L) \text {, Kulit tengah, } \\
\text { Kunyit warangan (Curcuma demostica), Triketuka } \\
\text { \{Kesuna (Allium sativum } L \text { ), Jangu (Acorus }\end{array}$ & $\begin{array}{l}\text { Dipakai sebagai } \\
\text { sembar }\end{array}$ \\
\hline
\end{tabular}


calamus), Mesui (Cryptocarya massoy (Oken)

Kosterm.)\}.

Tabia bungkut (Piper retrofractum , Piper longum L),

Mica gundil (Piper nigrum L), Kunyit (Curcuma

demostica).

Kulit wangkal, Triketuka \{Kesuna (Allium sativum $L$ ),

Jangu (Acorus calamus), Mesui (Cryptocarya

massoy (Oken) Kosterm.)\}

Batuk,

Rimpang isen (Alpinia galangal), Akar asem

dekah

(Tamarindus indica), Arak tahun

Batuk,

Lampuyang (Zingiber zerumbet), Isen (Alpinia

galangal), Daun pule (Alstonia scholaris (L.) R. Br.),

Katumbah (Coriandrum sativum L.), Air cendana

(Santalum album L.).

Katik pule (Alstonia scholaris (L.) R. Br.), Miana

cemeng (Coleus scutellarioides), Temu tis (Curcuma

purpurascens Blume), Air cendana (Santalum album

L.), Jruk linglang (Citrus aurantifolia)

Mawatuk
Batuk,
dekah

Kunir warangan (Curcuma demostica), Isin rong, gula

Daun mandori (Calotropis gigantean), Kunir

warangan (Curcuma demostica), Kencur

(Kaempferia galanga L), Lawos (Alpinia galangal), Bawang adas (Eleutherine palmifolia).

\begin{tabular}{|c|c|c|c|}
\hline $\begin{array}{l}\text { Tiwang } \\
\text { bangke }\end{array}$ & $\begin{array}{l}\text { Tergeletak seperti } \\
\text { mayat }\end{array}$ & $\begin{array}{l}\text { Trikatuka \{Kesuna (Allium sativum L), Jangu (Acorus } \\
\text { calamus), Mesui (Cryptocarya massoy (Oken) } \\
\text { Kosterm.)\}, Jebugarum (Myristica fragrans Hout.), } \\
\text { Sampar wantu (Sindora sumatrana Miq), Katik } \\
\text { cengkeh (Syzygium aromaticum), Katumbah } \\
\text { (Coriandrum sativum L.), Daun sumaga bali (Citrus } \\
\text { nobilis), Daun bangle (Zingiber cassumunar), Kunir } \\
\text { warangan (Curcuma demostica), Mica gundil (Piper } \\
\text { nigrum L). }\end{array}$ & $\begin{array}{l}\text { Digerus, airnya } \\
\text { diminum, } \\
\text { ampasnya dipakai } \\
\text { sebagai bedaknya. }\end{array}$ \\
\hline $\begin{array}{l}\text { Tiwang } \\
\text { bebai }\end{array}$ & $\begin{array}{l}\text { Perut kram, daerah di } \\
\text { bawah perut sakit } \\
\text { seperti ditarik }\end{array}$ & $\begin{array}{l}\text { Kapkap (Piper betle } L) \text {, Tingkih (Aleurites } \\
\text { moluccanus (L.) Willd), Temu tis (Curcuma } \\
\text { purpurascens Blume), Kelapa dibakar (Cocos } \\
\text { nucifera } L \text { ). }\end{array}$ & $\begin{array}{l}\text { Dipakai sebagai } \\
\text { obat dengan cara } \\
\text { disembarkan }\end{array}$ \\
\hline $\begin{array}{l}\text { Tiwang } \\
\text { leyak }\end{array}$ & $\begin{array}{l}\text { Daerah perut terasa } \\
\text { sakit seperti diulet- } \\
\text { ulet, tiak bisa } \\
\text { bernapas, tidak bisa } \\
\text { menelan }\end{array}$ & $\begin{array}{l}\text { Babakan tibah (Morinda citrifolia L), Uyah } \\
\text { Babakan mendep, Triketuka }\{\text { Kesuna (Allium } \\
\text { sativum L), Jangu (Acorus calamus), Mesui } \\
\text { (Cryptocarya massoy (Oken) kosterm.)\} }\end{array}$ & $\begin{array}{l}\text { Disembar sakitnya } \\
\text { Dipakai sebagai } \\
\text { obat minum }\end{array}$ \\
\hline $\begin{array}{l}\text { Tiwang } \\
\text { jaran }\end{array}$ & $\begin{array}{l}\text { Mulutnya bengar- } \\
\text { bengor seperti mulut } \\
\text { kuda }\end{array}$ & $\begin{array}{l}\text { Akar dalundung (Erythrina euodiphylla Hassk), Akar } \\
\text { kapas (Gossypium hirsutum L), Bras bang (Oryza } \\
\text { nivara), Triketuka \{Kesuna (Allium sativum L), Jangu } \\
\text { (Acorus calamus), Mesui (Cryptocarya massoy } \\
\text { (Oken) Kosterm.)\} }\end{array}$ & $\begin{array}{l}\text { Dipakai sebagai } \\
\text { bedaknya. }\end{array}$ \\
\hline $\begin{array}{l}\text { Tuju } \\
\text { gantung }\end{array}$ & $\begin{array}{l}\text { Terasa mual, } \\
\text { dahaknya keluar } \\
\text { berwarna kuning }\end{array}$ & $\begin{array}{l}\text { Jahe pait (Zingiber officinale Roxb), Asem } \\
\text { (Tamarindus indica), Air limo (Citrus amblicarpa). }\end{array}$ & Dimakan \\
\hline Tuju upas & Terasa sangat lemas & $\begin{array}{l}\text { Sari kuning, Dalima (Punica granatum L), Sajeng } \\
\text { manis } \\
\text { Daun dapdap wong (Erythrina euodiphylla Hassk), } \\
\text { Sari kuning, Adas (Foeniculum vulgare). }\end{array}$ & $\begin{array}{l}\text { Dimakan } \\
\text { Digerus kemudian } \\
\text { dibedakkan }\end{array}$ \\
\hline $\begin{array}{l}\text { Tiwang } \\
\text { macan }\end{array}$ & & $\begin{array}{l}\text { Isi bluluk (Arenga pinnata (Wurmb) Merr.), Mica } \\
\text { (Piper nigrum L), Ingu (Ruta angustifolia), Trasi } \\
\text { bang, Wrak }\end{array}$ & Dimakan \\
\hline Tiwang asu & $\begin{array}{l}\text { Mulut menyeringai } \\
\text { dengan gigi kelihatan } \\
\text { seperti anjing galak }\end{array}$ & $\begin{array}{l}\text { Daun sungsang, Pangi (Pangium edule), Kesuna } \\
\text { (Allium sativum), Jangu (Acorus calamus), Bras } \\
\text { bang (Oryza nivara), Bawang (Allium cepa). }\end{array}$ & Dibedakkan \\
\hline $\begin{array}{l}\text { Tiwang } \\
\text { upas } \\
\text { gatel }\end{array}$ & Bersin-bersin & Daun sangga, Gendis, Santen kane & Dimakan \\
\hline $\begin{array}{l}\text { Batuk dan } \\
\text { meludah } \\
\text { terus } \\
\text { menerus } \\
\text { dan mual- } \\
\text { mual }\end{array}$ & & $\begin{array}{l}\text { Temu tis (Curcuma purpurascens Blume), Daun } \\
\text { paya, Lunak tanek (Tamarindus indica). }\end{array}$ & $\begin{array}{l}\text { Sangrai } \\
\text { (nyahnyah), } \\
\text { kemudian digerus } \\
\text { sampai halus } \\
\text { ditambah air } \\
\text { sedikit kemudian } \\
\text { disaring, airnya } \\
\text { diminum dan } \\
\text { ampasnya dipakai } \\
\text { menempel hulu } \\
\text { hati. }\end{array}$ \\
\hline
\end{tabular}

Dadah sedikit, kemudian diminum

Dipakai sebagai urap

Dipakai sebaga sembar

Dipakai sebaga sembar

Dimakan

Dipakai sebagai

bedaknya

Dipakai sebagai

obat minum

Digerus, airnya

diminum

ampasnya dipaka

Kosterm.)\},

cengkeh (Syzygium aromaticum), Katumbah

(Coriandrum sativum L.), Daun sumaga bali (Citrus nobilis), Daun bangle (Zingiber cassumunar), Kunir

obat dengan cara

Disembar sakitnya

Dipakai sebaga

Babakan mendep, Triketuka \{Kesuna (Allium

sativum L), Jangu (Acorus calamus), Mesui

Akar dalundung (Erythrina euodiphylla Hassk), Akar

Dipakai sebaga

nivara), Triketuka \{Kesuna (Allium sativum L), Jangu

(Acorus calamus), Mesui (Cryptocarya massoy

Dimakan

Dimakan

igerus kemudian dibedakkan Isi bluluk (Arenga pinnata (Wurmb) Merr.), Mica Dimakan (Piper nigrum L), Ingu (Ruta angustifolia), Trasi g, Wrak

Dibedakkan seperti anjing galak bang (Oryza nivara), Bawang (

hati. 


\begin{tabular}{|c|c|c|}
\hline Mawatuk & $\begin{array}{l}\text { Kunir (Curcuma demostica), Katumbah (Coriandrum } \\
\text { sativum L.). }\end{array}$ & $\begin{array}{l}\text { Sembar di } \\
\text { tenggorokan }\end{array}$ \\
\hline Mewatuk & $\begin{array}{l}\text { Galih bras putih (Oryza sativa), Air cendana } \\
\text { (Santalum album L.), Jruk linglang (Citrus } \\
\text { aurantifolia). }\end{array}$ & Diminum \\
\hline Batuk & Rimpang isen (Alpinia galangal), Gendis (gula) & Dimakan \\
\hline Batuk & $\begin{array}{l}\text { Lawos (Alpinia galangal), Lunak tanek (Tamarindus } \\
\text { indica) }\end{array}$ & Dimakan \\
\hline Batuk & $\begin{array}{l}\text { Daun tingkih (Aleurites moluccanus (L.) Willd), Daun } \\
\text { dapdap tis (Erythrina variegate), Bawang (Allium } \\
\text { cepa) }\end{array}$ & Dipakai bedak \\
\hline $\begin{array}{l}\text { Batuk yang } \\
\text { sudah lama }\end{array}$ & Lunak tanek (Tamarindus indica). & Dimakan \\
\hline $\begin{array}{l}\text { Mawatuk } \\
\text { metu nanah }\end{array}$ & $\begin{array}{l}\text { Kunir (Curcuma demostica), Lunak tanek } \\
\text { (Tamarindus indica), Bawang (Allium cepa), Lengis } \\
\text { tanusan, Telur ayam digoreng }\end{array}$ & Dimakan \\
\hline $\begin{array}{l}\text { Batuk, } \\
\text { dahak tidak } \\
\text { bisa keluar }\end{array}$ & $\begin{array}{l}\text { Rimpang isen (Alpinia galangal), Air jruk linglang } \\
\text { (Citrus aurantifolia), Madu lebah }\end{array}$ & Diminum \\
\hline $\begin{array}{l}\text { Mawatuk tur } \\
\text { seret }\end{array}$ & $\begin{array}{l}\text { Teleng putih sekawit (Clitoria ternatea L), Kemeri } \\
\text { lanang (Aleurites moluccanus (L.) Willd). }\end{array}$ & Puhakena \\
\hline $\begin{array}{l}\text { Mokan } \\
\text { amacek }\end{array}$ & $\begin{array}{l}\text { Kunir (Curcuma demostica), Madori (Calotropis } \\
\text { gigantean) }\end{array}$ & Puhakena \\
\hline $\begin{array}{l}\text { Mokan } \\
\text { amacek }\end{array}$ & $\begin{array}{l}\text { Katik cengkeh (Syzygium aromaticum), Masui } \\
\text { (Cryptocarya massoy (Oken) Kosterm.) }\end{array}$ & Puhakena \\
\hline $\begin{array}{l}\text { Mokan } \\
\text { amacek }\end{array}$ & $\begin{array}{l}\text { Kulit kepel (Manglietia glauca), Air jruk linglang } \\
\text { (Citrus aurantifolia ). }\end{array}$ & Puhakena \\
\hline $\begin{array}{l}\text { Mokan } \\
\text { amacek }\end{array}$ & $\begin{array}{l}\text { Dapdap tis (Erythrina variegate), Lenge wangi } \\
\text { (Sesamum indicum L.), Sari lungid }\end{array}$ & Puhakena \\
\hline $\begin{array}{l}\text { Mokan } \\
\text { amacek }\end{array}$ & $\begin{array}{l}\text { Lenge wangi (Sesamum indicum L.), Air limo (Citrus } \\
\text { amblicarpa), Biji kapas }\end{array}$ & Puhakena \\
\hline Mokan & $\begin{array}{l}\text { Laos (Alpinia galangal), Jruk linglang (Citrus } \\
\text { aurantifolia), Arak, } \\
\text { Laos (Alpinia galangal), Isin rong, Daun nangka } \\
\text { (Artocarpus heterophyllus Lam), Daun bawang } \\
\text { (Allium cepa), Daun madori (Calotropis gigantean), } \\
\text { Daun waringin (Ficus benjamina). }\end{array}$ & $\begin{array}{l}\text { Madadah, } \\
\text { kemudian dipakai } \\
\text { sebagai usug } \\
\text { (lulur) } \\
\text { Dipakai sembar di } \\
\text { hulu hati }\end{array}$ \\
\hline Mokan & $\begin{array}{l}\text { Rimpang isen (Alpinia galangal), Limo (Citrus } \\
\text { amblicarpa). }\end{array}$ & Puhakena \\
\hline $\begin{array}{l}\text { Mokan } \\
\text { amacek }\end{array}$ & $\begin{array}{l}\text { Sulasih arum (Ocimum tenuiflorum), Menyan madu } \\
\text { (Styrax benzoin), Air cendana } \\
\text { (Santalum album L.), Jruk linglang (Citrus } \\
\text { aurantifolia). }\end{array}$ & Puhakena \\
\hline $\begin{array}{l}\text { Mokan, } \\
\text { kepala sakit } \\
\text { menusuk- } \\
\text { nusuk }\end{array}$ & $\begin{array}{l}\text { Mica (Piper nigrum } L) \text {, Daun dapdap tis } 7 \text { helai } \\
\text { (Erythrina variegate). }\end{array}$ & Sembarkan \\
\hline $\begin{array}{l}\text { Tiwang } \\
\text { sasah } \\
\text { bangke, } \\
\text { sakitnya } \\
\text { menusuk- } \\
\text { nusuk } \\
\text { sampai ke } \\
\text { punggung }\end{array}$ & $\begin{array}{l}\text { Temu tis (Curcuma purpurascens Blume), Kunir } \\
\text { warangan (Curcuma demostica), Jangu (Acorus } \\
\text { calamus), Menyan (Styrax benzoin), Kencur } \\
\text { (Kaempferia galanga L), Bangle (Zingiber } \\
\text { cassumunar). }\end{array}$ & Disembarkan \\
\hline $\begin{array}{l}\text { Mual-mual } \\
\text { tetapi } \\
\text { muntah } \\
\text { tidak keluar }\end{array}$ & Babakan bongli, Cekuh (Kaempferia galanga $L$ ) & $\begin{array}{l}\text { Disembar hulu } \\
\text { hatinya }\end{array}$ \\
\hline $\begin{array}{l}\text { Lumpuh } \\
\text { dan } \\
\text { sakitnya } \\
\text { meluang }\end{array}$ & $\begin{array}{l}\text { Akar tuwung kaji (Solanum surattense), Kapkap } \\
\text { (Piper betle L), Janganulam (Syzygium polyanthum } \\
\text { (Wight.) Walp). }\end{array}$ & Dibedakkan \\
\hline $\begin{array}{l}\text { Pejen metu } \\
\text { rah nanah }\end{array}$ & $\begin{array}{l}\text { Isep nanah- Isep getih, Bawang adas (Eleutherine } \\
\text { palmifolia), Bras bang (Oryza nivara). }\end{array}$ & Inum \\
\hline Mejen & $\begin{array}{l}\text { Babakan lempeni (Ardisia humilis Vahl), Kendal } \\
\text { batuka, Bras bang ( Oryza nivara) }\end{array}$ & Makan \\
\hline $\begin{array}{l}\text { Pejen, } \\
\text { dubur } \\
\text { keluar }\end{array}$ & $\begin{array}{l}\text { Kunir warangan (Curcuma demostica), Menyan } \\
\text { madu (Styrax benzoin) }\end{array}$ & $\begin{array}{l}\text { Direbus sedikit, } \\
\text { kemudian dimakan }\end{array}$ \\
\hline Pejen & Buni minced (Antidesma bunius L.), Babakan & Dimakan \\
\hline
\end{tabular}




\begin{tabular}{|c|c|c|}
\hline & $\begin{array}{l}\text { kusambi (Schleichera oleosa Lour), Bras bang } \\
\text { (Oryza nivara), Kulit bungsil (Cocos nunifera). }\end{array}$ & \\
\hline Pejen & $\begin{array}{l}\text { Pohon pisang krutuk yang masih muda (Musa } \\
\text { balbisiana Colla), Bawang adas (Eleutherine } \\
\text { palmifolia), Bras bang (Oryza nivara). }\end{array}$ & Dimakan \\
\hline Tuju & $\begin{array}{l}\text { Kayu book, Kunyit warangan (Curcuma demostica), } \\
\text { Trikatuka \{Kesuna (Allium sativum L), Jangu (Acorus } \\
\text { calamus), Mesui (Cryptocarya massoy (Oken) } \\
\text { Kosterm.)\}. }\end{array}$ & $\begin{array}{l}\text { Dipakai sebagai } \\
\text { bedak }\end{array}$ \\
\hline $\begin{array}{l}\text { Bahu sakit } \\
\text { terasa } \\
\text { meluang }\end{array}$ & $\begin{array}{l}\text { Tabia bun (Piper retrofractum, Piper longum L), } \\
\text { Bras barak (Oryza nivara), Cendana (Santalum } \\
\text { album L.), Jruk (Citrus maxima (Burm.f.) Merr). }\end{array}$ & $\begin{array}{l}\text { Dipakai sebagai } \\
\text { bedak }\end{array}$ \\
\hline Beteg & $\begin{array}{l}\text { Poh amplem (Mangifera indica L), Trikatuka }\{\text { Kesuna } \\
\text { (Allium sativum L), Jangu (Acorus calamus), Mesui } \\
\text { (Cryptocarya massoy (Oken) Kosterm.)\}. }\end{array}$ & $\begin{array}{l}\text { Dipakai sebagai } \\
\text { bedak }\end{array}$ \\
\hline Beteg & $\begin{array}{l}\text { Paya (Momordica charantia L.), Gamongan (Zingiber } \\
\text { zerumbet), Jruk linglang (Citrus aurantifolia) }\end{array}$ & $\begin{array}{l}\text { Dipakai sebagai } \\
\text { bedak }\end{array}$ \\
\hline Beteg & $\begin{array}{l}\text { Babakan kusambi (Schleichera oleosa Lour.), } \\
\text { Trikatuka \{Kesuna (Allium sativum L), Jangu (Acorus } \\
\text { calamus), Mesui (Cryptocarya massoy (Oken) } \\
\text { Kosterm.)\}, Arak }\end{array}$ & $\begin{array}{l}\text { Dipakai sebagai } \\
\text { bedak }\end{array}$ \\
\hline Beteg & $\begin{array}{l}\text { Daun jabon, Kesuna (Allium sativum), Jangu (Acorus } \\
\text { calamus), Daun badung (Garcinia dulcis) }\end{array}$ & $\begin{array}{l}\text { Dipakai sebagai } \\
\text { ses }\end{array}$ \\
\hline $\begin{array}{l}\text { Hulu hati } \\
\text { berdenyut- } \\
\text { denyut } \\
\text { keras }\end{array}$ & $\begin{array}{l}\text { Liligundi (Vitex trifolia L), Trikatuka }\{\text { Kesuna (Allium } \\
\text { sativum L), Jangu (Acorus calamus), Mesui } \\
\text { (Cryptocarya massoy (Oken) Kosterm.)\}, Isen } \\
\text { (Alpinia galangal), Jruk linglang (Citrus aurantifolia) }\end{array}$ & Dimakan \\
\hline $\begin{array}{l}\text { Jampi } \\
\text { gantung }\end{array}$ & $\begin{array}{l}\text { Pucuk pule (Alstonia scholaris (L.) R. Br.), } \\
\text { Pancarsona (Merremia mammosa), Kemeri } \\
\text { (Aleurites moluccanus (L.) Willd), Bawang (Allium } \\
\text { cepa), Trikatuka KKesuna (Allium sativum L), Jangu } \\
\text { (Acorus calamus), Mesui (Cryptocarya massoy } \\
\text { (Oken) Kosterm.)\}, Asaban candana (Santalum } \\
\text { album L.), Sari lungid, Bras matah (Oryza sativa). }\end{array}$ & Sembar \\
\hline
\end{tabular}

Praktik pengobatan tradisional di Bali umumnya dilaksanakan oleh pengusada atau balian yang mempunyai pengetahuan cukup tentang pengobatan tradisional tersebut. Pengetahuan tersebut diperoleh dengan berbagai cara seperti; karena turunan dari keluarga sebelumnya, taksu, pica, belajar atau nyastra, dan lainya. Dengan demikian Balian dapat dikelompokkan menjadi beberapa kelompok, yakni; (1) Balian Katakson merupakan Balian yang mendapat keahlian melalui taksu. Taksu berupa kekuatan spiritual yang dimiliki oleh seseorang serta telah mempengaruhi orang tersebut, baik cara berpikir, berbicara maupun berperilaku. Kekuatan Taksu tersebut memungkinkan sesorang mampu mengobati orang yang menderita sakit; (2) Balian Kapican merupakan balian yang memiliki kemampuan setelah memperoleh pica. Pica tersebut dapat berupa benda bertuah. Dengan mempergunakan pica tersebut, balian mempunyai kemampuan untuk menyembuhkan penyakit; (3) Balian Usada merupakan balian yang memiliki kemampuan pengobatan yang diperoleh melalui aktifitas belajar ilmu pengobatan, baik melalui guru waktra, belajar pada Balian, maupun belajar sendiri melalui lontar usada; (4) Balian Campuran merupakan Balian katakson maupun Balian kapican yang mempelajari usada (Nala, 2002).

Dalam melaksanakan pengobatan, seorang pengusadha umumnya mengikuti tata laksana pengobatan di antaranya; (1) ngelinggihan taksu yakni memohon 
kekuatan dan sinar suci dari Tuhan Yang Maha Esa Karena kecakapan atau pengetahuan yang dimiliki seroang pengusada berasal dari Tuhan yang Maha Esa sebagai kekuatan yang masuk kedalam jiwa, raga dan pikiran yang berwujud sebagai Taksu sang Pengusada, (2), pengraksa jiwa sang gering yakni sang gering melakukan pemujaan kepada Tuhan Yang Maha Esa agar memberikan kekuatan pada diri sang gering dan pengusada, (3) tetengering gering yakni pengenalan gejala penyakit (diagnosis), serta (4) pengobatan dengan menggunakan obat (PerGub Bali 55/Th 2019). Dalam usadha tiwang, tetengering gering terlihat dari pengenalan gejala-gejala penyakit, seperti tiwang utara dicirikan dengan gejala gelisah (meunyang-anyingan), mata mendelik. Tiwang tojos dicirikan dengan gejala gelisah (meunyang-anyingan), mata mendelik, serta tangan tidak mau diam (pati grèpè). Selanjutnya, dilakukan pengobatan dengan menggunakan berbagai jenis ramuan yang berasal dari tumbuhtumbuhan serta bahan-bahan lainnya. Seperti tiwang utara di obati dengan campuran Gamongan (Zingiber zerumbet), Triketuka \{Kesuna (Allium sativum L), Jangu (Acorus calamus), Mesui (Cryptocarya massoy (Oken) Kosterm), serta tain seksek. Bahanbahan tersebbut kemudian dihaluskan semuanya dan cara pengobatannya dengan cara diurapkan.

Namun demikian, cara pengolahan bahan atau sarana obat banyak yang belum dicantumkan secara jelas, seperti misalnya pengobatan terhadap tiwang kertas dengan menggunakan daun dapdap tis (Erythrina subumbrans), rimpang kunyit (Curcuma demostica), serta gula tebu, pengobatannya dengan cara diminumkan. Kondisi ini akan memunculkan interpretasi bahwa bahan tersbut dibuat dalam bentuk loloh terlebih dahulu sebelum diminum. Disamping itu takaran bahan-bahan atau sarana masih belum terungkap secara jelas. Bahkan Pengobatan tiwang bebek tidak dicantumkan cara pengobatannya. Tiwang bebek memiliki gejala Perut $n g r e d e k$ seperti suara lautan, dan diobati dengan campuran bahan yang terdiri atas Sembung (Blumea balsamifera (L.) DC.), Daringo (Acorus calamus), namun cara pemakaian atau pengobatannya belum jelas.

Penyakit atau gejala penyakit diobati dengan ramuan obat-obatan yang terbuat dari campuran berbagai jenis tumbuh-tumbuhan atau bahan lainnya. Penggunaannyapun bermacam-macam seperti dimakan, diminum, ditutuhkan, disemburkan, diuapkan atau dilulurkan, maupun ditempelkan. Tumbuhan tersebut ada yang digunakan dalam keadaan segar atau sudah dalam bentuk olahan seperti direbus atau ditambus. Tumbuhan tersebut ada yang diolah dalam bentuk boreh, loloh, sembar, tampel, atau tutuh. Boreh berupa campuran obat yang dibuat dengan 
cara menggiling ataupun menumbuk campuran bahan sampai halus kemudian ditambahkan air atau arak. Sedangkan loloh berupa sari pati yang diperoleh dengan cara meremas-remas atau menggerus bahan dengan menambahkan sedikit air kemudian diperas dan disaring.. Sembar atau simbuh yaitu berupa ramuan yang diperoleh dengan cara mengunyah bahan-bahan sampai lumat kemudian disemburkan secara langsung pada bagian badan yang diobati. Tampel atau tempel yaitu ramuan yang diperoleh dengan cara menghaluskan campuran bahan-bahan dan dalam penggunaannya ditempelkan pada bagian yang diobati. Tutuh Tutuh atau pepeh yaitu ramuan yang diambil dari sari pati dengan cara memeras atau menggiling bahan-bahannya kemudian disaring untuk mendapatkan sari patinya dan dalm penggunaannya diteteskan

Bahan lainya yang sering digunakan seperti arak, lengis tanusan yakni minyak kelapa yang dibuat secara tradisional, garam, gula, kapur, maupun santen, bahkan tain seksek serta iduh bang. Tain seksek yaitu serbuk kayu yang dihasilkan oleh ulat pemakan kayu, sedangkan iduh bang berupa air ludah berwarna merah setelah seseorang nginang atau makan sirih (nyirih).

Pemanfaatan tumbuhan tersebut disertai unsur non medis seperti mantramantra. Seperti salah satu mantra "Ong kita saking campah, kaupatana, tiwang asu, aku akokon, ong teja-teja, teka luar, 3. Ong sanghyang Indra angleburaken tiwang kabeh, tiwang bangke, tiwang asu, teka mati kita kabeh, ko sipok aku sipok, ong tejateja teka luar 3". Mantra-mantra yang disertai dengan sarana dan ritual pembersihan unsur abstrak, bertujuan melindungi pasien secara psikologis dan memotivasi untuk ketahanan bathin agar terhindar dari mara bahaya (fungsi preventif, promotif, rehabilitasif). Mantera memegang peranan penting dalam pengobatan oleh para pengobat tradisional. Tanpa mantera, segala bentuk sarana dianggap belum memiliki kekuatan supra natural dalam penyembuhan, karena tercapainya kesembuhan mutlak merupakan kuasa Tuhan, bukan oleh saran obat saja.

Penyakit tidak hanya merupakan gejala biologi saja, tetapi juga memiliki dimensi yang lain yakni sosial budaya. Menyembuhkan suatu penyakit tidak cukup hanya dengan menangani masalah biologinya saja, tetapi harus digarap masalah sosial budayanya. Masyarkat pada umumnya mencari pertolongan pengobatan bukanlah karena penyakit yang patogen, tetapi kebanyakan akibat adanya kelainan fungsi dari tubuhnya. Masyarakat di Bali masih percaya bahwa pengobatan tradisional usadha banyak maanfaatnya untuk menyembuhkan orang sakit. Walaupun telah banyak ada Puskesmas tersebar merata di setiap kecamatan, tetapi berobat ke pengobat tradisional Bali (Balian) masih merupakan pilihan yang tidak dapat 
dikesampingkan begitu saja baik bagi orang desa maupun orang kota. Oleh karena itu maka pelayanan kesehatan tradisional, baik emperis, komplementer maupun integratisi, sangat diperlukan oleh masyarakat Bali. Pelayanan kesehatan tradisional adalah pengobatan dan/atau perawatan dengan cara dan obat yang mengacu pada pengalaman dan keterampilan turun temurun secara empiris yang dapat dipertanggungjawabkan dan diterapkan sesuai dengan norma yang berlaku di masyarakat (UU RI. 36/Tahun 2009).

Masyarakat Bali tetap percaya terhadap pengobatan tradisional. Masyarakat Bali percaya bahwa sehat-sakit terjadi merupakan kombinasi antara shtula sarirasuksma sarira-antahkarana sarira yakni keseimbangan antara badan (Body), pikiran (Mind), dan jiwa (spirit). WHO juga menyatakan bahwa tiga karakteristik pengobatan tradisional yang membuat pasien percaya terhadap pengobatan tradisional adalah, pertama kepercayaan bahwa hidup adalah kesatuan dari badan, emosi, pikiran dan roh atau jiwa, dan kesehatan adalah keseimbangan antara beberapa aspek di dalam badan manusia dengan lingkungan. Penyakit akan terjadi bila tidak ada kesinambungan antara fisik, emosional, mental, atau spiritual. Kedua, pengobatan tradisional menggunakan pendekatan menyeluruh pada diagnosis dan tindakan, bukan melihat bagian per bagian tubuh. Ketiga, pengobatan tradisional berdasarkan pada kebutuhan individu, berbeda orang berbeda tindakan meskipun pada kasus penyakit yang sama (Jauhari et al., 2008).

Sistim pengobatan tersebut menggambarkan hubungan kompleks pengetahuan, kepercayaan dan pemanfaatan, yang disebut juga sebagai kompleks Corpus-Cosmos-Praxis. Kompleksitas tersebut menggambarkan bahwa, praktik (praxis) pemanfaatan tumbuhan dalam pengobatan dilandasi oleh sistim kepercayaan yang kuat (cosmos) dan sistim pengetahuan (corpus) (Arsana, 2019). Kondisi tersebut karena praktik pengobatan tradisional Bali telah berakar kuat dalam budaya masyarakat Bali, sehingga tidak bisa dipisahkan dari kehidupan sehari-hari. Kondisi tersebut karena kebudayaan Bali dapat dikatakan terbentuk dari proses interaksi manusia Bali dengan lingkungannya. Dalam kosmologi orang Bali, lingkungan dibedakan atas dua macam yakni lingkungan sekala (nyata) dan lingkungan niskala (tidak nyata). Lingkungan sekala meliputi lingkungan sosial (masyarakat) dan lingkungan fisik (alam sekitarnya). Sedangkan lingkungan niskala merupakan lingkungan spiritual yang dihuni oleh kekuatan-kekuatan supranatural atau adikodrati yang diyakini dapat menimbulkan pengaruh positif maupun negatif terhadap kehidupan manusia. Ekspresi dari interaksi antara orang Bali dengan lingkungan 
sosial antara lain melahirkan Basa Bali (Bahasa Bali), norma-norma, peraturanperaturan, hukum (sima, dresta, awig-awig), pranata-pranata sosial seperti pranata kekerabatan (nyama, braya, dadia, soroh), dan pranata kemasyarakatan (sekeha, banjar, desa, gumi). Ekspresi dari interaksi orang Bali dengan lingkungan fisik antara lain melahirkan sistem pengetahuan tentang alam (seperti penanggalan sasih, pawukon, pranatamangsa), sistem subak dan lain sebagainya. Ekspresi dari interaksi antara orang Bali dengan lingkungan spiritual (niskala) melahirkan sistem religi lokal atau "agama Bali" yang di dalamnya mencakup emosi atau sentimen keagamaan, konsepsi tentang kekuatan-kekuatan dan mahluk-mahluk gaib, upacara ritual keagamaan, fasilitas keagamaan, kelompok atau komunitas keagamaan (Pujaastawa, 2014).

Hal tersebut sesuai dengan konsep pelayanan kesehatan tradisional Bali yakni; (1) gangguan kesehatan individu disebabkan oleh ketidakseimbangan/harmoni bhuana alit (tubuh manusia) dengan bhuana agung (lingkungan alam semesta), unsur fisik, mental, sosial, spiritual, dan budaya; (2) manusia memiliki kemampuan beradaptasi dan penyembuhan diri sendiri (self healing); (3) penyehatan dilakukan dengan pendekatan holistik (menyeluruh) dan alamiah yang bertujuan untuk menyeimbangkan kembali antara kemampuan adaptasi dengan penyebab gangguan kesehatan (PerGub Bali 55/Th 2019).

\section{SIMPULAN}

Dari pembahasan di atas dapat disimpulkan bahwa Lontar Usadha Tiwang membahas tentang penyakit tiwang yakni penyakit yang mempunyai gejala badan terasa meluang, sakit dan ngilu, gelisah, mata mendelik, otot kaku bahkan sampai pingsan. Penyakit atau gejala penyakit diobati dengan ramuan obat-obatan yang terbuat dari campuran berbagai jenis tumbuh-tumbuhan atau bahan lainnya seperti arak, lengis tanusan, garam, gula, kapur, maupun santen, bahkan tain seksek serta iduh bang. Penggunaannya dimakan, diminum, ditutuhkan, disemburkan, diuapkan atau dilulurkan, maupun ditempelkan.

Masyarakat Bali tetap percaya terhadap pengobatan tradisional, bahwa sehatsakit terjadi merupakan kombinasi antara shtula sarira-suksma sarira-antahkarana sarira yakni keseimbangan antara badan (body), pikiran (mind), dan jiwa (spirit).

\section{REFERENSI}

Arsana, I. N. (2019). Keragaman Tanaman Obat dalam Lontar "Taru Pramana" dan Pemanfaatannya untuk Pengobatan Tradisional Bali. Jurnal Kajian Bali (Journal 
of Bali Studies), 9(1), 241. https://doi.org/10.24843/JKB.2019.v09.i01.p12.

Jauhari, A. H., Utami, M. S., \& Padmawati, R. S. (2008). Motivasi dan Kepercayaan Pasien untuk Berobat ke Sinse. Berita Kedokteran Masyarakat, 24(1), 1-7.

Nala, IGN. 1992. Usada Bali. (Balinese Traditional Healing). Upada Sastra. Denpasar.

Peraturan Gubernur Bali No 55 Tahun 2019 Tentang Pelayanan Kesehatan Tradisional Bali, (2019). http://jdih.baliprov.go.id.

Pujaastawa, I.B.G. 2014. Kebudayaan Bali. Makalah Disampaikan Dalam Pelatihan Kehumasan Polri Hotel Klapa Bali Pecatu Resort 22 Agustus 2014.

Undang-Undang Republik Indonesia No. 36 Tahun 2009 tentang Kesehatan.

Ventegodt, S., Thegler, S., Andreasen, T., Struve, F., Jacobsen, S., Torp, M., ÆEgedius, H., Enevoldsen, L., \& Merrick, J. (2007). A Review and Integrative Analysis of Ancient Holistic Character Medicine Systems. The Scientific World JOURNAL, 7 , $1821-1831$.

https://www.ncbi.nlm.nih.gov/pmc/articles/PMC5901236/pdf/TSWJ-2007-7567841.pdf

Yuan, H., Ma, Q., Ye, L., \& Piao, G. (2016). The traditional medicine and modern medicine from natural products. Molecules, 21(5). https://doi.org/10.3390/molecules21050559 